\title{
Evaluation of Lactocare ${ }^{\circledR}$ Synbiotic Administration on the Serum Electrolytes and Trace Elements Levels in Psoriasis Patients: a Randomized, Double-Blind, Placebo-Controlled Clinical Trial Study
}

\author{
Ali Akbarzadeh ${ }^{1} \cdot$ Mohammad Taheri $^{2} \cdot$ Bahareh Ebrahimi $^{3} \cdot$ Pedram Alirezaei $^{3} \cdot$ Amin Doosti-Irani $^{4}$. \\ Meysam Soleimani ${ }^{5} \cdot$ Fatemeh Nouri $^{5}$
}

Received: 15 October 2021 / Accepted: 4 November 2021 / Published online: 29 November 2021

(C) The Author(s), under exclusive licence to Springer Science+Business Media, LLC, part of Springer Nature 2021

\begin{abstract}
Background Despite the exact etiopathogenesis of psoriasis remains unknown, the increasing or decreasing of some trace elements and oxidative stress status are considered to play a role. In this study, the effect of Lactocare ${ }^{\circledR}$ synbiotic on the serum levels of trace elements including $\mathrm{Zn}, \mathrm{Cu}, \mathrm{Mg}, \mathrm{Na}, \mathrm{Fe}, \mathrm{P}, \mathrm{Ca}$, and $\mathrm{K}$ in the patients with mild to moderate psoriasis was investigated.

Methods Sixty-four patients with mild to moderate psoriasis were included. Patients were randomly divided into treatment $(n=32)$ and control $(n=32)$ groups. The treatment group received Lactocare ${ }^{\circledR}$ and the control group received a placebo (two times daily for 12 weeks). Eight patients from the intervention group and 18 patients from the control group discontinued the study because of the recent COVID-19 condition. For routine trace element analysis, the blood samples were collected from all patients at the baseline as well as week 12 post-treatment. The serum was then isolated and the serum levels of trace elements including $\mathrm{Fe}, \mathrm{K}, \mathrm{Ca}, \mathrm{Mg}, \mathrm{P}, \mathrm{Zn}, \mathrm{Na}$, and $\mathrm{Cu}$ were measured using an automatic electrolyte analyzer. For confirmation of the effect of Lactocare ${ }^{\circledR}$ on the alteration of serum levels of trace elements, intra-group analysis was performed at two interval times: baseline and week 12 post-treatment.

Results The serum levels of K, P, and Ca in the placebo group were significantly higher than that of the treatment group at baseline. Serum levels of $\mathrm{Zn}$ and $\mathrm{Ca}$ were significantly higher in the treatment group compared to the placebo group at week 12 post-treatment. Moreover, a significantly lower serum level of K, P, and $\mathrm{Ca}$ in the treatment group at the baseline compared to the placebo group was compensated on week 12 post-treatment. Intra-group analysis in the treatment group showed that the serum levels of $\mathrm{Fe}, \mathrm{Ca}, \mathrm{Mg}, \mathrm{P}, \mathrm{Zn}$, and $\mathrm{Na}$ was significantly increased at week 12 post-treatment compared to baseline levels. Whereas, intra-group analysis in the control group showed only $\mathrm{Ca}$ has a significant difference between baseline and week 12 post-treatment.

Conclusion The serum levels of $\mathrm{Fe}, \mathrm{Zn}, \mathrm{P}, \mathrm{Mg}, \mathrm{Ca}$, and $\mathrm{Na}$ are increased significantly 12 weeks after oral administration of Lactocare ${ }^{\circledR}$ in psoriatic patients. The serum level of $\mathrm{Fe}$ and $\mathrm{Cu}$ is affected by sex at pre- and post-treatment. This study supports the concept that Lactocare ${ }^{\circledR}$ exerts beneficial effects in the gastrointestinal tract to improve mineral absorption in psoriatic patients.
\end{abstract}

Keywords Electrolyte $\cdot$ Trace element $\cdot$ Psoriasis $\cdot$ Probiotic

Ali Akbarzadeh and Mohammad Taheri had equal contributions.

Fatemeh Nouri

Fatemenouri1@gmail.com

1 Student Research Committee, Hamadan University of Medical Sciences, Hamadan, Iran

2 Department of Medical Microbiology, Faculty of Medicine, Hamadan University of Medical Sciences, Hamadan, Iran

3 Psoriasis Research Center, Hamadan University of Medical Sciences, Hamadan, Iran
4 Department of Epidemiology, School of Public Health and Research Center for Health Sciences, Hamadan University of Medical Sciences, Hamadan, Iran

5 Department of Pharmaceutical Biotechnology, School of Pharmacy, Hamadan University of Medical Sciences, Hamadan, Iran 


\section{Introduction}

Psoriasis is a chronic inflammatory and autoimmune disease that is accompanied by psychosocial disability and metabolic changes $[1,2]$. Approximately 2 to $3 \%$ of the world's population suffers from the psoriasis [3]. It is clinically characterized by erythematous plaques covered with white silvery crust [4]. This disease has a genetic predisposition and is caused by stimuli such as trauma, infection, medication, and stress [5]. The common idea is that oxidative stress causes inflammation that plays a role in etiopathogenesis. Also, increasing or decreasing some trace elements are considered to play a role [6-8]. On the other hand, reactive oxygen species (ROS) which is produced from neutrophils, keratinocytes, and fibroblasts can activate neutrophils which can lead to the inflammatory process of psoriasis [9-11]. Myeloperoxidase (MPO) forms ROS during the degranulation of activated polymorphonuclear leukocytes (PMNL). However, ROS can cause tissue damage and oxidative stress when it is overproduced in this way [12]. Regarding psoriasis, excess ROS and a decline in endogenous antioxidant activities (such as SOD) are observed [13]. SOD has been reported to contain $\mathrm{Cu}$ and $\mathrm{Zn}$ and changes in the activity of this enzyme can lead to changes in the level of these elements $[14,15]$.

Trace elements have been reported to be essential for biochemical and immunological processes in the body $[16,17]$. Trace elements not only play important roles in immunologic and inflammatory responses but also their deficiencies or excesses affect the enzyme-dependent processes such as keratinization and melanin formation [18]. There is a discrepancy about the effect of some trace elements on the pathogenesis of psoriasis. Zinc (Zn) and copper $(\mathrm{Cu})$ are two important trace elements involved in the progression and development of psoriasis. The abnormality of these two trace elements as important mechanisms underlying the occurrence of psoriasis has been widely reported [19-23].

Disruption of intestinal microbiome composition leads to an imbalance between innate and adaptive immunity which can lead to psoriasis. On the other hand, it has been shown that probiotics can play a role in improving psoriasis by replacing the intestinal microbiome [24]. Probiotics are nonpathogenic exogenous microorganisms that if used in sufficient quantities are beneficial for atopic dermatitis, psoriasis, and acne [25-27]. Probiotics can modulate T lymphocytes by regulating the composition of the gut microbiome and preventing psoriasis [24, 28]. Prebiotics(such as oligosaccharides)are fermented substances that improve the activity of intestinal flora [29]. There is evidence that probiotics and prebiotics can be used to improve the absorption of minerals (such as calcium and iron) from foods consumed [30].
Animal studies have also shown that the administration of probiotics can change some serum levels of trace elements [31]. Since there is a discrepancy about the serum levels of trace elements in the psoriasis patients and synbiotics have a beneficial effect on quality of the life and improve the disease as well as their effect on the trace elements in psoriasis, this study was aimed to evaluate the effect of Lactocare ${ }^{\circledR}$ synbiotic on the serum levels of trace elements.

\section{Material and Methods}

\section{Ethics Consideration}

This double-blind, randomized, placebo-controlled study was first registered in the Iranian Registry of Clinical Trials (IRCT20120215009014N323). The study project was approved by the Ethics Committee Hamadan University of Medical Sciences, Hamadan, Iran. Informed consent (in Persian) was obtained from all participants after explaining the goals of the study to the patients.

\section{Study Subjects}

This study was conducted on patients with mild to moderate psoriasis who were referred to the Hakim laboratory of Hamadan from May 2021 to Aug 2021. Mild to moderate psoriasis was defined according to the psoriasis severity and surface area (PASI) and dermatology life quality index (DLQI). On this basis, psoriasis severity was defined using the following criteria: mild, PASI $<7$ and DLQI $<7$; moderate, PASI $=7-15$ and DLQI $=5-15$ (classified as severe when difficult-to-treat sites are affected or when there is a significant psychosocial impact); severe, PASI $>15$, independently of the DLQI score [32].

\section{Sample Size}

Sixty-four psoriatic patients were enrolled in this clinical trial study. Patients were then allocated randomly into 32 in the intervention group and 32 in the placebo group. Eight patients from the intervention group and 18 patients from the control group discontinued the study because of the recent COVID-19 condition. The sample size was calculated based on a power of $80 \%$ and a statistical significance $(\alpha)$ of $95 \%$ $(p=0.05)$.

\section{Study Protocol}

All patients were enrolled in the clinical trial according to the same protocol. The severity of psoriasis was determined according to PASI and DLQI assessed by questionnaires. Eligible patients aged between 18 and 60 years were 
randomly divided into two groups including the treatment group and the placebo group. The treatment group received Lactocare ${ }^{\circledR}$ (ZistTakhmir, Iran) capsules containing seven strains (including Lactobacillus casei, Lactobacillus acidophilus, Lactobacillus rhamnosus, Lactobacillus bulgaricus, Bifidobacterium breve, Bifidobacterium longum, Streptococcus thermophiles with prebiotic fructooligosaccharide) twice daily for 12 weeks. Lactocare ${ }^{\circledR}$ was provided in capsules containing $1 \times 10^{9} \mathrm{CFU}$ kept in the refrigerator at $4{ }^{\circ} \mathrm{C}$. Placebo was also provided in similar packages with no identification sign, which was prepared by the same company of the probiotic (ZistTakhmir Company) containing starch and kept in the same situation. The packages were just labeled as A or B and neither physicians nor patients knew the containing materials. Hematological analysis was done before the beginning of the experiment (baseline) and week 12 post-treatment. For routine trace element analysis, the blood samples were collected from all patients at the baseline as well as week 12 post-treatment. The serum was then isolated and the serum levels of trace elements including $\mathrm{Fe}, \mathrm{K}, \mathrm{Ca}, \mathrm{Mg}, \mathrm{P}, \mathrm{Zn}, \mathrm{Na}$, and $\mathrm{Cu}$ were measured. The serum levels of $\mathrm{Na}$ and $\mathrm{K}$ were measured using an automatic electrolyte analyzer (BIOLYTE 2000, $\mathrm{UK}$ ). The levels of $\mathrm{Cu}, \mathrm{Mg}, \mathrm{P}, \mathrm{Fe}$, and $\mathrm{Zn}$ were analyzed using the specific kits for each trace element (Biomed) by an automatic analyzer (Hitachi, Japan).

\section{Inclusion Criteria}

Patients aged 18 to 60 years psoriatic patients; 2 - mild to moderate patients $(0<\mathrm{PASI}<15$ and $0<\mathrm{DLQI}<15)$.

Exclusion criteria.

1. use of any probiotic or immunosuppressive drug within the last 6 weeks before study entry;

2. The immunosuppressed patients and the patients with diabetes;

3. Use of antibiotics within the last 2 weeks before study entry

\section{Statistical analysis}

Data analyses were performed using SPSS version 22. The mean of the serum levels of trace elements of the placebo groups was compared to the treatment group using an independent $t$-test. Intragroup analysis was done using Repeatedmeasure ANOVA. The data were expressed as mean \pm standard error of the mean (SEM) and $P<0.05$ was considered as statistical difference.

\section{Results}

\section{Demographical Findings}

A total of 36 patients (20 male and 16 female) completed the study. Out of 22 patients in the treatment group, 3 patients $(59.1 \%)$ were male and 9 patients $(40.9 \%)$ were female. Whereas, out of 14 patients in the control group 7 patients $(50 \%)$ were male and $7(50 \%)$ were female. There was no significant difference between the control and treatment groups concerning sex $(P>0.05)$.

\section{Hematological Findings}

\section{Placebo compared to treatment}

The results of the hematological analysis in both groups at baseline and week 12 post-treatment are shown in Table 1 . A significant difference was seen in the treatment group compared to the placebo respected to the serum levels of $\mathrm{Ca}(P=0.01), \mathrm{K}(P=0.01)$, and $\mathrm{P}(P=0.05)$ at baseline as well as the serum levels of $\mathrm{Zn}(P=0.01)$ and $\mathrm{Ca}(P=0.001)$ at week 12 Post-treatment. There was no significant difference between the treatment group and the placebo group in terms of other hematological elements $(P>0.05)$ (Table 1$)$.

Table 1 Comparison of hematological findings in the treatment group compared to the placebo group at baseline and week 12 post-treatment

\begin{tabular}{lccl}
\hline Variables & $\begin{array}{l}\text { Treatment } \\
\text { Mean } \pm \text { SEM }\end{array}$ & $\begin{array}{l}\text { Placebo } \\
\text { Mean } \pm \text { SEM }\end{array}$ & $P$ value \\
\hline $\mathrm{Fe}(\mu \mathrm{g} / \mathrm{d} 1)$ baseline & $71.90 \pm 5.15$ & $75.921 \pm 6.91$ & 0.63 \\
$\mathrm{Fe}(\mu \mathrm{g} / \mathrm{d} 1)$ Post-T & $83.45 \pm 4.56$ & $71.07 \pm 7.84$ & 0.15 \\
$\mathrm{~K}(\mathrm{mEq} / \mathrm{L})$ baseline & $3.96 \pm 0.09$ & $4.32 \pm 0.08$ & 0.011 \\
$\mathrm{~K}(\mathrm{mEq} / \mathrm{L})$ Post-T & $4.15 \pm 0.05$ & $4.30 \pm 0.16$ & 0.37 \\
$\mathrm{Ca}(\mathrm{mg} / \mathrm{d} 1)$ baseline & $9.14 \pm 0.12$ & $9.65 \pm 0.13$ & 0.010 \\
$\mathrm{Ca}(\mathrm{mg} / \mathrm{d} 1)$ Post-T & $9.67 \pm 0.10$ & $8.97 \pm 0.17$ & 0.001 \\
$\mathrm{Mg}(\mathrm{mg} / \mathrm{d} 1)$ baseline & $2.05 \pm 0.03$ & $2.141 \pm 0.3$ & 0.08 \\
$\mathrm{Mg}(\mathrm{mg} / \mathrm{d} 1)$ Post-T & $2.15 \pm 0.02$ & $2.07 \pm 0.04$ & 0.07 \\
$\mathrm{P}(\mathrm{mg} / \mathrm{d} 1)$ baseline & $3.35 \pm 0.16$ & $3.82 \pm 0.13$ & 0.05 \\
$\mathrm{P}(\mathrm{mg} / \mathrm{d} 1)$ Post-T & $3.83 \pm 0.12$ & $3.53 \pm 0.08$ & 0.08 \\
$\mathrm{Zn}(\mu \mathrm{g} / \mathrm{d} 1)$ baseline & $91.90 \pm 3.80$ & $92.64 \pm 4.02$ & 0.89 \\
$\mathrm{Zn}(\mathrm{pg} / \mathrm{d} 1)$ Post-T & $101.86 \pm 3.17$ & $87.42 \pm 4.33$ & 0.012 \\
$\mathrm{Na}(\mathrm{mEq} / \mathrm{L})$ baseline & $138.77 \pm 0.96$ & $141.35 \pm 1.29$ & 0.12 \\
$\mathrm{Na}(\mathrm{mEq} / \mathrm{L})$ Post-T & $140.951 \pm 0.74$ & $138.78 \pm 1.29$ & 0.12 \\
$\mathrm{Cu}(\mu \mathrm{g} / \mathrm{d} 1)$ baseline & $121.50 \pm 10.26$ & $124.21 \pm 10.97$ & 0.86 \\
$\mathrm{Cu}(\mu \mathrm{g} / \mathrm{d} 1)$ Post-T & $110.13 \pm 7.26$ & $109.21 \pm 10.61$ & 0.94 \\
\hline
\end{tabular}

Post-T post-treatment; SEM standard error of mean 
Table 2 Comparison of serum levels of trace elements at baseline and week 12 post-treatment in the treatment group

\begin{tabular}{lrrr}
\hline Variable/time & \multicolumn{1}{l}{$\begin{array}{l}\text { Baseline } \\
\text { Mean } \pm \text { SEM }\end{array}$} & \multicolumn{1}{l}{$\begin{array}{l}\text { Week 12 } \\
\text { Mean } \pm \text { SEM }\end{array}$} & $P$ value \\
\hline $\mathrm{Fe}(\mu \mathrm{g} / \mathrm{d} 1)$ & $71.90 \pm 5.15$ & $83.45 \pm 4.56$ & .008 \\
$\mathrm{~K}(\mathrm{mEq} / \mathrm{L})$ & $3.96 \pm 0.09$ & $4.15 \pm 0.05$ & .106 \\
$\mathrm{Ca}(\mathrm{mg} / \mathrm{d} 1)$ & $9.14 \pm 0.12$ & $9.67 \pm 0.10$ & .000 \\
$\mathrm{Mg}(\mathrm{mg} / \mathrm{d} 1)$ & $2.05 \pm 0.03$ & $2.15 \pm 0.02$ & .012 \\
$\mathrm{P}(\mathrm{mg} / \mathrm{d} 1)$ & $3.35 \pm 0.16$ & $3.83 \pm 0.12$ & .004 \\
$\mathrm{Zn}(\mu \mathrm{g} / \mathrm{d} 1)$ & $91.90 \pm 3.80$ & $101.86 \pm 3.17$ & .033 \\
$\mathrm{Na}(\mathrm{mEq} / \mathrm{L})$ & $138.77 \pm 0.96$ & $140.95 \pm 0.74$ & .038 \\
$\mathrm{Cu}(\mu \mathrm{g} / \mathrm{d} 1)$ & $121.50 \pm 10.26$ & $110.13 \pm 7.26$ & .154 \\
\hline
\end{tabular}

Post-T post-treatment; SEM standard error of mean

\section{Hematological analysis in the treatment group at baseline and week 12 post-treatment}

For evaluation of the effect of treatment on the blood hematological changes, the blood elements at baseline were compared to week 12 post-treatment and the obtained data are shown in Table 2. In the treatment group, the intragroup analysis showed that the mean serum levels of $\mathrm{Fe}$ $(P=0.008), \mathrm{Ca}(\mathrm{P}=0.001), \mathrm{Mg}(P=0.012), \mathrm{P}(P=0.004)$, $\mathrm{Zn}(P=0.033)$, and Na were significantly different at baseline compared to week 12 post-treatment (Table 2). There was no significant difference between baseline and week 12 post-treatment in terms of serum level of other trace elements $(P>0.05)$ (Table 2).

\section{Hematological analysis in the placebo group at baseline and week 12 post-treatment}

For evaluation of the changes of serum levels of trace elements in the control group, the serum levels of trace elements at baseline were compared to week 12 post-treatment and the obtained data are shown in Table 3. In the control group, the intra-group analysis showed that the mean serum level of $\mathrm{Ca}(P=0.007)$ was significantly different at baseline compared to week 12 post-treatment (Table 3). There was no significant difference between baseline and week 12 posttreatment in terms of serum level of other trace elements $(P>0.05)$ (Table 3).

\section{Hematological findings based on sex in the treatment group}

Except for serum level of baseline $\mathrm{Fe}$ and $\mathrm{Cu}$ post-treatment, there was no significant difference between male and female patients in the treatment group in terms of trace elements serum levels at baseline and week 12 post-treatment $(P>0.05)$ (Table 4).
Table 3 Comparison of serum levels of trace elements at baseline and week 12 post-treatment in the placebo group

\begin{tabular}{lccc}
\hline Variable/time & $\begin{array}{l}\text { Baseline } \\
\text { Mean } \pm \text { SEM }\end{array}$ & $\begin{array}{l}\text { Week 12 } \\
\text { Mean } \pm \text { SEM }\end{array}$ & $P$ value \\
\hline $\mathrm{Fe}(\mu \mathrm{g} / \mathrm{d} 1)$ & $75.92 \pm 6.91$ & $71.07 \pm 7.84$ & 0.568 \\
$\mathrm{~K}(\mathrm{mEq} / \mathrm{L})$ & $4.32 \pm 0.08$ & $4.30 \pm 0.16$ & 0.948 \\
$\mathrm{Ca}(\mathrm{mg} / \mathrm{d} 1)$ & $9.65 \pm 0.13$ & $8.97 \pm 0.17$ & 0.007 \\
$\mathrm{Mg}(\mathrm{mg} / \mathrm{d} 1)$ & $2.14 \pm 0.3$ & $2.07 \pm 0.04$ & 0.204 \\
$\mathrm{P}(\mathrm{mg} / \mathrm{d} 1)$ & $3.82 \pm 0.13$ & $3.53 \pm 0.08$ & 0.069 \\
$\mathrm{Zn}(\mu \mathrm{g} / \mathrm{d} 1)$ & $92.64 \pm 4.02$ & $87.42 \pm 4.33$ & 0.238 \\
$\mathrm{Na}(\mathrm{mEg} / \mathrm{L})$ & $141.35 \pm 1.29$ & $138.78 \pm 1.29$ & 0.179 \\
$\mathrm{Cu}(\mu \mathrm{g} / \mathrm{d} 1)$ & $124.21 \pm 10.97$ & $109.21 \pm 10.61$ & 0.259 \\
\hline
\end{tabular}

Post-T post-treatment; SEM standard error of mean

\section{Hematological findings based on sex in the placebo group}

Except for serum level of baseline $\mathrm{K}(P=0.031)$ and $\mathrm{Zn}$ post-treatment $(P=0.025)$, there was no significant difference between male and female patients in the placebo group in terms of serum trace elements levels at baseline and week 12 post-treatment $(P>0.05)$ (Table 5).

\section{Discussion}

In this study, the effect of Lactocare ${ }^{\circledR}$ on the serum levels of trace elements including $\mathrm{Zn}, \mathrm{Cu}, \mathrm{Mg}, \mathrm{Na}, \mathrm{Fe}, \mathrm{P}, \mathrm{Ca}$, and $\mathrm{K}$ in patients with psoriasis was investigated. The significant increasing serum levels of $\mathrm{Fe}, \mathrm{Zn}, \mathrm{P}, \mathrm{Mg}, \mathrm{Ca}$, and $\mathrm{Na}$, 12 weeks after oral administration of Lactocare ${ }^{\circledR}$ in psoriatic patients were the main finding of the current study. The serum levels of $\mathrm{K}, \mathrm{P}$, and $\mathrm{Ca}$ in the placebo group were significantly higher than that of the treatment group at baseline. While serum levels of $\mathrm{Zn}$ and $\mathrm{Ca}$ were significantly higher in the treatment group compared to the placebo group at week 12 post-treatment. Moreover, a significantly lower serum level of $\mathrm{K}, \mathrm{P}$, and $\mathrm{Ca}$ in the treatment group at the baseline compared to the placebo group was compensated on week 12 post-treatment. Lactocare ${ }^{\circledR}$ had no beneficial effect on serum levels of $\mathrm{Cu}$.

Psoriasis is a chronic, inflammatory, and immune-mediated disease characterized by the development of scaly, sharply demarcated erythematous, pruritic, indurated, and often painful skin plaques[33]. Despite the exact etiopathogenesis of psoriasis remains unknown, the increasing or decreasing of some trace elements and oxidative stress status are considered to play a role [8]. In a study by Sudhakar et al. serum electrolytes level was measured in psoriasis patients. This study was based on 25 patients and 25 controls with an age range of 20 to 60 years old. It was shown that the sodium level $(151.04 \pm 3.79 ; p<0.0001)$ and sodium 
Table 4 Comparison of serum levels of trace elements at baseline and week 12 post-treatment between female and male patients in the treatment group

\begin{tabular}{|c|c|c|c|}
\hline Variable/sex & & $\begin{array}{l}\text { Treatment } \\
\text { Mean } \pm \text { SEM }\end{array}$ & $P$ value \\
\hline Fe Baseline ( $\mu \mathrm{g} / \mathrm{d} 1)$ & $\begin{array}{l}\text { Male } \\
\text { Female }\end{array}$ & $\begin{array}{r}80.84 \pm 6.76 \\
59.00 \pm 5.99\end{array}$ & 0.033 \\
\hline Fe Post-T $(\mu \mathrm{g} / \mathrm{d} 1)$ & $\begin{array}{l}\text { Male } \\
\text { Female }\end{array}$ & $\begin{array}{l}86.53 \pm 6.04 \\
79.00 \pm 7.11\end{array}$ & 0.430 \\
\hline $\mathrm{K}$ baseline $(\mathrm{mEq} / \mathrm{L})$ & $\begin{array}{l}\text { Male } \\
\text { Female }\end{array}$ & $\begin{array}{l}3.92 \pm 0.11 \\
4.02 \pm 0.14\end{array}$ & 0.607 \\
\hline K Post-T (mEq/L) & $\begin{array}{l}\text { Male } \\
\text { Female }\end{array}$ & $\begin{array}{l}4.11 \pm 0.06 \\
4.18 \pm 0.09\end{array}$ & 0.524 \\
\hline Ca Baseline (mg/d1) & $\begin{array}{l}\text { Male } \\
\text { Female }\end{array}$ & $\begin{array}{l}9.16 \pm 0.13 \\
9.12 \pm 0.23\end{array}$ & 0.877 \\
\hline Ca Post-T (mg/d1) & $\begin{array}{l}\text { Male } \\
\text { Female }\end{array}$ & $\begin{array}{l}9.61 \pm 0.15 \\
9.76 \pm 0.12\end{array}$ & 0.489 \\
\hline Mg Baseline (mg/d1) & $\begin{array}{l}\text { Male } \\
\text { Female }\end{array}$ & $\begin{array}{l}2.07 \pm 0.04 \\
2.02 \pm 0.05\end{array}$ & 0.490 \\
\hline Mg Post-T (mg/d1) & $\begin{array}{l}\text { Male } \\
\text { Female }\end{array}$ & $\begin{array}{l}2.15 \pm 0.02 \\
2.14 \pm 0.03\end{array}$ & 0.894 \\
\hline P Baseline (mg/d1) & $\begin{array}{l}\text { Male } \\
\text { Female }\end{array}$ & $\begin{array}{l}3.35 \pm 0.16 \\
3.34 \pm 0.34\end{array}$ & 0.981 \\
\hline P Post-T (mg/d1) & $\begin{array}{l}\text { Male } \\
\text { Female }\end{array}$ & $\begin{array}{l}3.67 \pm 0.15 \\
4.06 \pm 0.17\end{array}$ & 0.122 \\
\hline Zn Baseline $(\mu \mathrm{g} / \mathrm{d} 1)$ & $\begin{array}{l}\text { Male } \\
\text { Female }\end{array}$ & $\begin{array}{l}97.53 \pm 4.63 \\
83.77 \pm 5.66\end{array}$ & 0.077 \\
\hline Zn Post-T $(\mu \mathrm{g} / \mathrm{d} 1)$ & $\begin{array}{l}\text { Male } \\
\text { Female }\end{array}$ & $\begin{array}{r}103.76 \pm 4.45 \\
99.11 \pm 4.47\end{array}$ & 0.484 \\
\hline Na Baseline (mEq/L) & $\begin{array}{l}\text { Male } \\
\text { Female }\end{array}$ & $\begin{array}{l}138.92 \pm 1.32 \\
138.55 \pm 1.44\end{array}$ & 0.856 \\
\hline Na Post-T (mEq/L) & $\begin{array}{l}\text { Male } \\
\text { Female }\end{array}$ & $\begin{array}{l}141.92 \pm 1.00 \\
139.55 \pm 9.8\end{array}$ & 0.122 \\
\hline Cu Baseline $(\mu \mathrm{g} / \mathrm{d} 1)$ & $\begin{array}{l}\text { Male } \\
\text { Female }\end{array}$ & $\begin{array}{l}105.69 \pm 9.62 \\
144.33 \pm 19.10\end{array}$ & 0.062 \\
\hline $\mathrm{Cu}$ Post-T $(\mu \mathrm{g} / \mathrm{d} 1)$ & $\begin{array}{l}\text { Male } \\
\text { Female }\end{array}$ & $\begin{array}{c}96.15 \pm 4.13 \\
130.33 \pm 14.66\end{array}$ & 0.05 \\
\hline
\end{tabular}

Post-T post-treatment; SEM standard error of mean

to potassium ratio $(44.999 \pm 5.37 ; p<0.0001)$ in patients were higher than control but potassium level $(3.352 \pm 0.28$; $p<0.0001$ ) was lower than control [34]. In a study by $\mathrm{HH}$ Qadim et al., 98 hospitalized cases with psoriasis were compared with 100 patients who were hospitalized due to other diseases. Among them, $37.2 \%$ were hypocalcemic and $63.7 \%$ had normal serum calcium. There was no hypercalcemia. In the other group, $9 \%$ were hypocalcemic, 89 and $2 \%$ were normocalcemic and hypercalcemic respectively [35].

Inducing oxidative stress and production of ROS have been suggested to play role in the etiopathogenesis of many skin chronic inflammatory diseases [8]. In particular,
Table 5 Comparison of serum levels of trace elements at baseline and week 12 post-treatment between female and male patients in the control group

\begin{tabular}{|c|c|c|c|}
\hline Variable/sex & & Placebo & $P$ value \\
\hline \multirow[t]{2}{*}{ Fe Baseline $(\mu \mathrm{g} / \mathrm{d} 1)$} & Male & $74.57 \pm 7.03$ & 0.850 \\
\hline & Female & $77.28 \pm 12.54$ & \\
\hline \multirow[t]{2}{*}{ Fe Post-T $(\mu \mathrm{g} / \mathrm{d} 1)$} & Male & $79.14 \pm 12.88$ & 0.322 \\
\hline & Female & $63.00 \pm 8.86$ & \\
\hline \multirow[t]{2}{*}{$\mathrm{K}$ baseline $(\mathrm{mEq} / \mathrm{L})$} & Male & $4.50 \pm 0.11$ & 0.031 \\
\hline & Female & $4.14 \pm 0.08$ & \\
\hline \multirow[t]{2}{*}{ K Post-T (mEq/L) } & Male & $4.28 \pm 0.29$ & 0.904 \\
\hline & Female & $4.32 \pm 0.18$ & \\
\hline \multirow[t]{2}{*}{ Ca Baseline (mg/d1) } & Male & $9.67 \pm 0.22$ & 0.921 \\
\hline & Female & $9.64 \pm 0.17$ & \\
\hline \multirow[t]{2}{*}{ Ca Post-T (mg/d1) } & Male & $8.82 \pm 0.29$ & 0.424 \\
\hline & Female & $9.12 \pm 0.20$ & \\
\hline \multirow[t]{2}{*}{ Mg Baseline (mg/d1) } & Male & $2.16 \pm 0.06$ & 0.671 \\
\hline & Female & $2.12 \pm 0.03$ & \\
\hline \multirow[t]{2}{*}{ Mg Post-T (mg/d1) } & Male & $2.02 \pm 0.05$ & 0.315 \\
\hline & Female & $2.11 \pm 0.05$ & \\
\hline \multirow[t]{2}{*}{ P Baseline (mg/d1) } & Male & $3.94 \pm 0.19$ & 0.373 \\
\hline & Female & $3.70 \pm 0.17$ & \\
\hline \multirow[t]{2}{*}{ P Post-T (mg/d1) } & Male & $3.60 \pm 0.15$ & 0.485 \\
\hline & Female & $3.47 \pm 0.08$ & \\
\hline \multirow[t]{2}{*}{ Zn Baseline $(\mu \mathrm{g} / \mathrm{d} 1)$} & Male & $99.42 \pm 5.35$ & 0.092 \\
\hline & Female & $85.85 \pm 5.11$ & \\
\hline \multirow[t]{2}{*}{ Zn Post-T $(\mu \mathrm{g} / \mathrm{d} 1)$} & Male & $96.71 \pm 5.62$ & 0.025 \\
\hline & Female & $78.14 \pm 4.60$ & \\
\hline \multirow[t]{2}{*}{$\mathrm{Na}$ Baseline $(\mathrm{mEq} / \mathrm{L})$} & Male & $143.28 \pm 1.84$ & 0.146 \\
\hline & Female & $139.42 \pm 1.61$ & \\
\hline \multirow[t]{2}{*}{ Na Post-T (mEq/L) } & Male & $139.71 \pm 1.24$ & 0.49 \\
\hline & Female & $137.85 \pm 2.33$ & \\
\hline \multirow[t]{2}{*}{$\mathrm{Cu}$ Baseline $(\mu \mathrm{g} / \mathrm{d} 1)$} & Male & $132.14 \pm 15.03$ & 0.492 \\
\hline & Female & $116.28 \pm 16.56$ & \\
\hline \multirow[t]{2}{*}{$\mathrm{Cu}$ Post-T $(\mu \mathrm{g} / \mathrm{d} 1)$} & Male & $107.85 \pm 16.35$ & 0.904 \\
\hline & Female & $110.57 \pm 14.85$ & \\
\hline
\end{tabular}

Post-T post-treatment; SEM standard error of mean

regarding psoriasis, excess ROS and a decline in endogenous antioxidant activities (such as SOD) are observed [13]. SOD has been reported to contain $\mathrm{Cu}$ and $\mathrm{Zn}$ and changes in the activity of this enzyme can cause as a result of changes in the level of these elements $[14,15]$. In a study, Goud et al. concluded that a decrease in serum levels of antioxidant vitamins, calcium, and phosphorus are the probable causative agents for the pathogenesis of psoriasis [36]. Suworow et al. Showed that magnesium deficiency is one of the causes of skin damage in psoriasis [37]. In a study by Shahidi et al. in 2012, the level of zink, magnesium, and copper in psoriatic patients was evaluated and their relationship with disease severity was investigated. Subjects included patients $(n=40)$ 
and the control group $(n=40)$. Zink and copper levels were higher in psoriatic patients than in the control group but magnesium level was lower in psoriatic patients than in the control group [18]. Probiotics and prebiotics by enhancing absorption of trace minerals and immunomodulatory effects and preventing inflammatory processes can be useful for psoriasis $[18,24,28,30]$. In a study by Rincón D. et al., the effect of probiotics was evaluated in 17 cirrhotic patients. This probiotic is a combination of Streptococcus salivarius, Bifidobacterium longum, Bifidobacterium breve, Bifidobacterium infantis, Lactobacillus acidophilus, Lactobacillus plantarum, Lactobacillus delbrueckii, and Lactobacillus casei. The results showed serum sodium level increased from $135.1 \pm 3.8 \mathrm{mEq} / \mathrm{L}$ to $138.0 \pm 3.1 \mathrm{mEq} / \mathrm{L}(\mathrm{P}=0.009)$ [38]. In a study by Véronique Ducros et al., the effect of fructooligosaccharides on the uptake of zinc, copper, and selenium in postmenopausal women was investigated. This double-blind study was performed on 11 patients aged 53 to 70 years. It was seen that the copper uptake was significantly increased but zink and selenium uptake did not change [39]. In another study by Silva MR. et al., the effect of Lactobacillus acidophilus on the iron level in 190 preschool children was investigated. Children were divided to test and control groups. The control group received iron-fortified milk and the test group also received probiotic fortified milk. It was specified that erythrocyte level in the test group was higher than the control group and they showed a positive correlation between iron absorption and hemoglobin level in the test group. This study showed that there is a positive relationship between the bioavailability of iron and fortified milk with Lactobacillus acidophilus [40].

In a study by Gonzalez et al., the effect of Lactobacillus fermentum on iron absorption was evaluated. They observed that $L$. fermentum by its reductive oxidative activity increases iron absorption from the intestine. L. fermentum secretes p-hydroxyphenyl acetic acid which reduces $\mathrm{Fe}$ (III) to Fe(II). This function leads to improved iron absorption through enterocytes' DMTI channels [41]. In research by Bernat N. et al., the effect of milk fortified with $L$. rhamnosus, B. bifidum, B. longum, and Streptococcus thermophiles on iron uptake from Caco-2 cells was checked out and it was observed that the bioavailability of iron improved $(p<0.05)[42]$.

In a study, A. Ballini et al. investigated the effect of four probiotics (B.lactis, B.infantis, L. plantarum, and $L$. acidophilus) on the level of vitamin A and vitamin D and absorption of minerals such as zink, iron, and calcium in 40 people. Individuals were divided into test $(n=20)$ and control groups $(n=20)$. The vitamin A level in the test group increased by $9 \%$ but in the control group by $1 \%$. Vitamin D levels increased by $3.2 \%$ in the test group but in the control group by $3 \%$. also the level of trace elements increased in the test group but decreased in the control group [43].
Finally, in the current study, the effect of sex on the serum levels of trace elements at baseline and week 12 post-treatment in male and female patients was compared. We have found that in the treatment group the male patients have a significant difference in serum levels of $\mathrm{Fe}$ baseline and $\mathrm{Cu}$ post-treatment compared to the female patients, respectively. In the placebo group, the male patients have a significant difference in serum levels of $\mathrm{K}$ baseline and $\mathrm{Zn}$ post-treatment compared to the female patients, respectively. These findings show that the serum level of these trace elements is affected by sex on pre and post-treatment. It has been shown that the concentration of $\mathrm{Fe}$ in the male patients with lichen planus was significantly different than that of the female, respectively [44]. According to Frei et al., (29) specific probiotics, prebiotics, or their combination named synbiotic such as Lactocare $囚$ in present work, significantly affect host immunological networks. Therefore, immune responses to microbial components are being better characterized at a molecular level. Finally, the immune-modulatory effects of synbiotics may be most potent when administered early in life. Also, it is proposed that in immunologic diseases such as psoriasis, electrolyte, and trace element imbalances were occurred, so probiotic administration help to the physiological balance of electrolytes and trace elements.

\section{Conclusion}

Many types of research indicated the involvement of probiotics in human health by acting through a different mechanism. Several studies have shown the positive effects of probiotics on improving mineral absorption. Our study showed that the serum levels of $\mathrm{Fe}, \mathrm{Zn}, \mathrm{P}, \mathrm{Mg}, \mathrm{Ca}$, and $\mathrm{Na}$ are increased significantly 12 weeks after oral administration of Lactocare ${ }^{\circledR}$ in psoriatic patients. The serum level of $\mathrm{Fe}$ and $\mathrm{Cu}$ is affected by sex at pre and post-treatment. Further studies including a larger group of psoriasis patients and a regular followup of serum electrolytes may improve the understanding of the role of probiotics in enhancing trace elemental levels in psoriatic patients.

\section{Study Limitation}

Since the present study was conducted at the time of the corona pandemic, the lack of cooperation of all patients and the exclusion of some of them from the study was the main limitation of the present study.

Author Contribution The conception and design of the study: F.N and M.T; acquisition of data, analysis, and interpretation of data: A.A, P.A, B.E, A.D, and F.N; drafting the article: A.A and F.N; revising the 
article critically for important intellectual content: M.T, B.E, M.S, and F.N; final approval of the version to be submitted: All authors.

Funding This work was supported financially by Hamadan University of Medical Sciences, Hamadan, Iran (Grant Numbers: 9906183916 and 9906184095).

Data Availability All data are available via the corresponding author.

Code Availability Not applicable.

\section{Declarations}

Ethics Approval This study has been approved by the Ethics Committee of Hamadan University of Medical Sciences. Hamadan, Iran (IR. UMSHA.REC.1399.408 and IR.UMSHA.REC.1399.407).

Conflict of Interest The authors declare no competing interests.

\section{References}

1. Dobrzyńska I, Szachowicz-Petelska B, Wroński A, Jarocka-Karpowicz I, Skrzydlewska E (2020) Changes in the physicochemical properties of blood and skin cell membranes as a result of psoriasis vulgaris and psoriatic arthritis development. Int J Mol Sci 21(23):9129

2. Fleming P, Kraft J, Gulliver WP, Lynde C (2015) The relationship of obesity with the severity of psoriasis: a systematic review. J Cutan Med Surg 19(5):450-456

3. Christophers E (2001) Psoriasis- epidemiology and clinical spectrum. Clin Exp Dermatol 26(4):314-320

4. Bidaki EZ, Zargari F, Mansouri P, Malekian A, Najafizade P (2011) Lesion area assessment in psoriasis patients. J Med Eng Technol 35(3-4):154-160

5. Kamiya K, Kishimoto M, Sugai J, Komine M, Ohtsuki M (2019) Risk factors for the development of psoriasis. Int J Mol Sci 20(18):4347

6. Armstrong AW, Voyles SV, Armstrong EJ, Fuller EN, Rutledge JC (2011) Angiogenesis and oxidative stress: common mechanisms linking psoriasis with atherosclerosis. J Dermatol Sci 63(1):1-9

7. Nazıroğlu M, Yıldız K, Tamtürk B, Erturan İ, Flores-Arce M (2012) Selenium and psoriasis. Biol Trace Elem Res 150(1):3-9

8. Kirmit A, Kader S, Aksoy M, Bal C, Nural C, Aslan O (2020) Trace elements and oxidative stress status in patients with psoriasis. Advances in Dermatology and Allergology/Postẹpy Dermatologii i Alergologii 37(3):333

9. Popov I, Lewin G (1991) A deficient function of the antioxidative system of the organism as an aetiopathogenetic factor in psoriasis. Med Hypotheses 35(3):229-236

10. Raynaud F, Evain-Brion D, Gerbaud P, Marciano D, Gorin I, Liapi C et al (1997) Oxidative modulation of cyclic AMP-dependent protein kinase in human fibroblasts: possible role in psoriasis. Free Radical Biol Med 22(4):623-632

11. Turner CP, Toye AM, Jones OT (1998) Keratinocyte superoxide generation. Free Radical Biol Med 24(3):401-407

12. Borawski J (2006) Myeloperoxidase as a marker of hemodialysis biocompatibility and oxidative stress: the underestimated modifying effects of heparin. Am J Kidney Dis 47(1):37-41

13. Guarneri F, Bertino L, Pioggia G, Casciaro M, Gangemi S (2021) Therapies with Antioxidant Potential in Psoriasis, Vitiligo, and Lichen Planus. Antioxidants 10(7):1087
14. Kocyigit A, Erel O, Gur S (2001) Effects of tobacco smoking on plasma selenium, zinc, copper and iron concentrations and related antioxidative enzyme activities. Clin Biochem 34(8):629-633

15. McMillan E, Rowe D (1983) Plasma zinc in psoriasis: relation to surface area involvement. Br J Dermatol 108(3):301-305

16. Bahrami A, Arabestani MR, Taheri M, Farmany A, Zadeh FN, Hosseini SM, et al (2021) Exploring the Role of Heavy Metals and Their Derivatives on the Pathophysiology of COVID-19. Biological Trace Element Research

17. Taheri M, Bahrami A, Habibi P, Nouri F (2021) A Review on the Serum Electrolytes and Trace Elements Role in the Pathophysiology of COVID-19. Biol Trace Elem Res 199(7):2475-2481

18. Mohammad S-D, Nastaran N, Sara K, Shima Y (2012) Trace elements status in psoriasis and their relationship with the severity of the disease. Iran J Dermatology 15(2):38-41

19. Basavaraj K, Darshan M, Shanmugavelu P, Rashmi R, Mhatre AY, Dhanabal $S$ et al (2009) Study on the levels of trace elements in mild and severe psoriasis. Clin Chim Acta 405(1-2):66-70

20. Lei L, Su J, Chen J, Chen W, Chen X, Peng C (2019) Abnormal serum copper and zinc levels in patients with psoriasis: A metaanalysis. Indian J Dermatol 64(3):224

21. Afridi HI, Kazi TG, Kazi N, Kandhro GA, Baig JA, Shah AQ et al (2011) Evaluation of cadmium, chromium, nickel, and zinc in biological samples of psoriasis patients living in Pakistani cement factory area. Biol Trace Elem Res 142(3):284-301

22. Ala S, Shokrzadeh M, Golpour M, Salehifar E, Alami M, Ahmadi A (2013) Zinc and copper levels in Iranian patients with psoriasis: a case control study. Biol Trace Elem Res 153(1):22-27

23. Nigam $P(2005)$ Serum zinc and copper levels and $\mathrm{Cu}: \mathrm{Zn}$ ratio in psoriasis. Indian J Dermatol Venereol Leprol 71(3):205-206

24. Alesa DI, Alshamrani HM, Alzahrani YA, Alamssi DN, Alzahrani NS, Almohammadi ME (2019) The role of gut microbiome in the pathogenesis of psoriasis and the therapeutic effects of probiotics. J Fam Med Prim Care 8(11):3496

25. Hill C, Guarner F, Reid G, Gibson GR, Merenstein DJ, Pot B et al (2014) The International Scientific Association for Probiotics and Prebiotics consensus statement on the scope and appropriate use of the term probiotic. Nat Rev Gastroenterol Hepatol 11(8):506-514

26. Pessemier BD, Grine L, Debaere M, Maes A, Paetzold B, Callewaert C (2021) Gut-Skin Axis: Current Knowledge of the Interrelationship between Microbial Dysbiosis and Skin Conditions. Microorganisms 9(2):353

27. Khani S, M Hosseini H, Taheri M, R Nourani M, A Imani Fooladi A (2012) Probiotics as an alternative strategy for prevention and treatment of human diseases: a review. Inflammation \& AllergyDrug Targets (Formerly Current Drug Targets-Inflammation \& Allergy) (Discontinued) 11(2) 79-89

28. Mallon PT, McKay D, Kirk SJ, Gardiner K (2007) Probiotics for induction of remission in ulcerative colitis. Cochrane Database of Systematic Reviews (4)

29. Frei R, Akdis M, O’Mahony L (2015) Prebiotics, probiotics, synbiotics, and the immune system: experimental data and clinical evidence. Curr Opin Gastroenterol 31(2):153-158

30. Sheridan PO, Bindels LB, Saulnier DM, Reid G, Nova E, Holmgren K, et al (2014) Can prebiotics and probiotics improve therapeutic outcomes for undernourished individuals? : Taylor \& Francis

31. Skrypnik K, Bogdański P, Schmidt M, Suliburska J (2019) The effect of multispecies probiotic supplementation on iron status in rats. Biol Trace Elem Res 192(2):234-243

32. Llamas-Velasco M, De la Cueva P, Notario J, Martínez-Pilar L, Martorell A, Moreno-Ramírez D (2017) Moderate psoriasis: a proposed definition. Actas Dermo-Sifiliográficas (English Edition) 108(10):911-917 
33. Korman N (2020) Management of psoriasis as a systemic disease: what is the evidence? Br J Dermatol 182(4):840-848

34. Sudhakar T, Sabitha V, Raj Kumar G, Jhansi Rani C, Pratyusha P, Bheem J et al (2018) Evaluation of Serum Electrolytes among Psoriasis Patients: A Prospective Case-Control Study from Telangana. South India Biochemi Anal Biochem 7(04):1-4

35. Qadim H, Goforoushan F, Nejad S, Goldust M (2013) Studying the calcium serum level in patients suffering from psoriasis. Pak J Biol Sci: PJBS 16(6):291-294

36. Goud BM, Avinash S, Amareshwara M (2010) Antioxidant vitamins, calcium and phosphorus levels in psoriasis. Int J Pharm Bio Sci 1(4):98

37. Suworow A (1990) Regulation of peptide hydrolase activity in psoriasis. Dermatol Monatsschr 176(7):393-397

38. Rincón D, Vaquero J, Hernando A, Galindo E, Ripoll C, Puerto $\mathrm{M}$ et al (2014) Oral probiotic VSL\# 3 attenuates the circulatory disturbances of patients with cirrhosis and ascites. Liver Int 34(10):1504-1512

39. Ducros V, Arnaud J, Tahiri M, Coudray C, Bornet F, BouteloupDemange $C$ et al (2005) Influence of short-chain fructo-oligosaccharides (sc-FOS) on absorption of $\mathrm{Cu}, \mathrm{Zn}$, and $\mathrm{Se}$ in healthy postmenopausal women. J Am Coll Nutr 24(1):30-37
40. Silva MR, Dias G, Ferreira CL, Franceschini SC, Costa NM (2008) Growth of preschool children was improved when fed an iron-fortified fermented milk beverage supplemented with Lactobacillus acidophilus. Nutr Res 28(4):226-232

41. González A, Gálvez N, Martín J, Reyes F, Pérez-Victoria I, Dominguez-Vera JM (2017) Identification of the key excreted molecule by Lactobacillus fermentum related to host iron absorption. Food Chem 228:374-380

42. Bernat N, Cháfer M, Chiralt A, Laparra JM, González-Martínez C (2015) Almond milk fermented with different potentially probiotic bacteria improves iron uptake by intestinal epithelial (Caco-2) cells. Int J Food Stud 4(1)

43. Ballini A, Gnoni A, De Vito D, Dipalma G, Cantore S, Gargiulo Isacco C et al (2019) Effect of probiotics on the occurrence of nutrition absorption capacities in healthy children: A randomized double-blinded placebo-controlled pilot study. Eur Rev Med Pharmacol Sci 23(19):8645-8657

44. Fahimeh R, Mahshid S (2018) Plasma level of trace elements in patients with oral lichen planus. Iran J Dermatol 21(2):54-58

Publisher's Note Springer Nature remains neutral with regard to jurisdictional claims in published maps and institutional affiliations. 